Chapter 29

\title{
HISTORY OF LOS ANGELES HARBOR
}

\author{
H. W. McOuat \\ Chief, River and Harbor Planning Section \\ Los Angeles District, Corps of Engineers \\ Department of the Army \\ Los Angeles, California
}

The writer wonders if the person who assigned the subject of "History of Los Angeles Harbor" was aware that the conference was to be held in the Long Beach Municipal Auditorium. This latter city also has a harbor, the development of which is now so interwoven with that of Los Angeles that the Corps of Engineers in many official papers refers to "Los Angeles and Long Beach Harbors, California."

In the evolution of this large, modern, combined harbor with its present friendly internal rivalry, it has been designated by a number of names. Cabrillo in 1542 called the place "Bahia de $10 s$ Humos." On the charts V1zcaino, 1602-1603, It appears as "Ensenada de San Andres." In 1734, the Spanish Admiral Gonzales gave it the name San Pedro, which st1ll applies to the bay as a whole and to the community along the westerly side of the harbor.

In the state of nature, Point Fermin provided protection from westerly wind and wave. Catalina Island to the south intercepted some of the wave action from that direction. Thus, for all except southeasterly storms to which it was wide open, the roadstead offered reasonable protection. The bottom held anchors well. Inland lay a land-locked lagoon which was later to play a major role in the development of the port (Fig. 1). Concurrent with the founding of the mission of San Gabriel in 1771, and the pueblo of Los Angeles by a small colony of monks from that mission in 1781 , came the regular use of the roadstead at San Pedro for loading and unloading of vessels.

Most of the nations of Europe had colonies throughout the world and were very jealous of them as outlets for home products and as sources of raw materials. Spain probably stood at the top in its all-out effort to keep foreigners out of her colonies and foreign vessels out of her colonial harbors. Probably the first American ship to come to San Pedro was the Lelia Byrd in 1805. Enroute back to Boston from the Hawailan Islands, Captain Shaler, unable to get meat at Avalon on Catalina Island, came on to San Pedro and readily obtained hogs and sheep in exchange for Yankee-manufactured goods. Although a penalty of death and forfelture of property faced the colonist convicted of trading with foreigners, this visit of the Lelia Byrd started a brisk contraband trade with Yankee and other forelgn shlps. First they came for otter sklns and later for cow hides and tallow. They brought cloth and sugar and household goods of every kind. Very little money changed hands.

Rebelilon against Spain was in progress during this period, and in 1822 came word of the relinquishment by spain of her Western possessions. Under the succeeding Mexican rule all ports were declared open, but duties averaging about 25 percent were levied. San Pedro was made a port of entry in 1826, but w1th the collector for the port stationed in Los Angeles there was little, if any, payment of duty. In July of 1828 , the port was again closed to forelgn vessels and headquarters for these vessels were moved to Catalina Island. In the year 1835, the port was visited by Richard Henry Dana and later described in his famous book, "Two Years Before the Mast."

In 1827, a grant of several thousand acres of land, known as the Palos Verde Rancho, was made. This rancho followed the San Pedro Bay shore on the west, but reserved for public use about 42 acres of land with $1,400 \mathrm{ft}$. of water frontage where Fort MacArthur's lower reservation is now located. With the confirmation of this grant in 1846, the headquarters of foreign ships came back from catalina and from this "Embarcadero" the business of the port was carried on for a number of years. With the return of the headquarters to the mainland came also the American occupation of the locality. In 1848 followed the Treaty of Guadalupe Hidalgo by which the United States acquired California. In $1850 \mathrm{California}$ was admitted to the Union. 


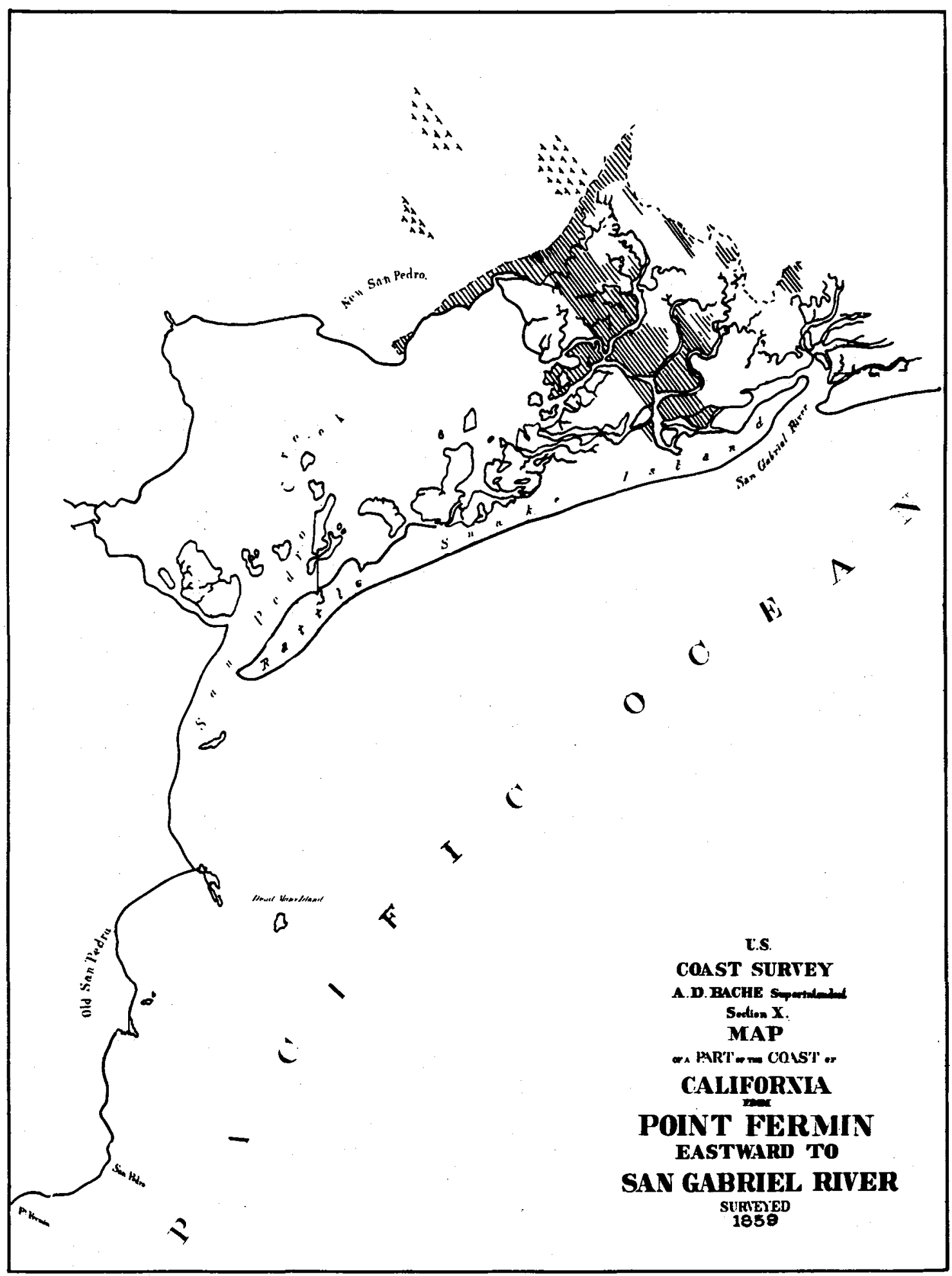

Fig. 1 
Phineas Banning, who played a large part in the early history of the port, came to the county in 1851. His first position was clerk in a forwarding estab11shment at the "Embarcadero." He and his associates in 1853 bought 2, 400 acres of land on the inner harbor from Manuel Dominguez, a grantee, for \$1.10 per acre. On this land he laid out a town and named it for his birthplace, Wilmington, Delaware. To this inner harbor were shallow shifting entrances on both sides of Deadman's Island. One account says that about a mile north of Deadman's Island there were two or three entering channels having from two to six ft. of water at low tide, while to the west of this island were generally depths of only one to three feet. All these channels were very crooked and unstable, but Banning along with others found it profitable to take the lighters through these channels to and from a point about where the Catalina Terminal now stands. The cargoes had to be lightered anyhow and the added miles on a scow were directly toward the ultimate destination, Los Angeles, and into calm water. Wagon transport could in no way compete with water borne for as far as the latter could be effected.

one point of agreement in the Treaty of Hidalgo was that the United states would honor all grants. To do this literally would have been impossible, due to conflicting and overlapping grants and numerous claims, many of which were fraudulent. In order to settle the titles, a special Federal Commission was appointed in 1851 to determine the proper boundaries and rightful owners. The Federal District Court passed finally on the findings of the Commission in each case. A survey and description by metes and bounds followed, which was the basis for issuance of a patent to the owner by the United States.

When the Rancho San Pedro grant was surveyed in December, 1857, the outside boundary lines were described, after which that part of wilmington Bay coming within these lines was specifically excepted in the following terms -- "Excepting, reserving and excluding from said tract, as thus surveyed, that portion thereof covered by the navigable waters of the inner bay of San Pedro, and which are included within the following described lines, to-wit ...."

In retrospect, it would seem that here was a natural for a publicly controlled port of large proportions. Here was 1,400 acres, capable of easy dredging and resultant fills, abutted by flat terrain for factories, railroads, etc., and with promise of a rich and populous surrounding territory. And fust that has occurred, but not without struggles, first to get a harbor at all and then to get it under public control.

Perhaps an occurrence in May of 1860 was a precursor of one of the things to come. Hordes of sharks swarmed in the waters of the local bay and became the basis of a short-lived oll industry. After the sharks were speared and hauled ashore, use was made only of the livers, which were bolled down and thus yielded an oil which burned fairly well in lamps. This oll brought a good price in Los Angeles in those early days, when no one dreamed of the oil in the earth under these same waters.

Times were hard during the sixties. Following a long, dry spell, during which thousands of cattle died and many rancheros and businessmen failed, ranchos were offered for delinquent taxes. The 28,000-acre Los Alamitos ranch, including the area where the City of Iong Beach now stands, was offered for sale in 1866 for delinquent taxes amounting to $\$ 152.65$, with no takers. It later sold for sixty cents an acre.

In the late sixties, Banning who had become a state senator got the city and County of Los Angeles to finance a rallroad costing $\$ 225,000$ between the Pueblo and Wilmington. The road was 23 miles long and the only railroad in the southland. It began operation in 1868 and was an immediate stimulus to the commerce at the port.

Prior to 1871, all the improvements "up the creek" had been minor and private1y financed. In this year, the people of Los Angeles became conscious of the harbor and held mass meetings to consider means for improving the harbor at wilmington. A survey was made and data gathered to present to Congress. Banning made several trips to Washington. The idea advanced was to confine the tidal prism averaging some $250,000,000 \mathrm{cu}$. ft. to a limited single channel with a view to using the tidal flow as a dredging force. 
On March 2, 1871, Congress adopted a project which contemplated straightening and deepening the channel between Deadman's Island and Timm's Point in San Pedro to $10 \mathrm{ft}$. This required closing the gap between Rattlesnake and Deadman's Islands. The estimated total cost of the project was $\$ 530,000$, with the initial appropriation amounting to $\$ 200,000$.

The closing jetty between the islands was built on a curve and in three sections. Its total length was about $6,700 \mathrm{ft}$. The initial 3,700 $\mathrm{ft}$. beginning at Rattlesnake Island consisted of a single line of double sheet piling, well braced and rising about one $\mathrm{ft}$. above high water. The next 1,000 ft. consisted of two parallel rows of 12 -in. sheet piling $10 \mathrm{ft}$. apart, strongly braced and partially filled with brush, stone gravel, and sand. The 2,000 ft. next to Deadman's Island was rubble mound projecting several feet above high water.

It was assumed that sand would accumulate on the seaward side of the jetty in quantities and soon enough to make the wooden jetty permanent without repairs. This assumption was not weil founded and there were a number of breaks especially along the lines of the old channels. Spurs and groins built out to intercept the sand helped but little. Original construction with concurrent repair ran from 1871 to 1881 and further repair ran on to 1903. By that time, some of the single sheet pile had been transformed into solld timber bulkhead consisting of timbers up to $18 \mathrm{in.} \mathrm{wide} \mathrm{securely} \mathrm{drifted} \mathrm{together.} \mathrm{The} \mathrm{entire} \mathrm{length} \mathrm{had} \mathrm{been} \mathrm{more} \mathrm{or}$ less reinforced with dumped stone.

While the jetty was not a total success structuraliy, it performed the function intended, and a good channel with a least depth of $10 \mathrm{ft}$. was scoured close to Deadman's Island. The use of this shallow channel was sufficient to warrant considering a deeper one and in 1881 a project to get $15 \mathrm{ft}$. of depth was adopted. This contemplated the extension of the east jetty beyond Deadman's Island to the 3-fathom curve and the construction of a correlating west jetty projecting 3,500 ft. from Timm's Point in the general direction of Deadman's Island and then southerly. Scour was to be given assistance this time by dredging the hardest portion. This work was completed in 1893 and was successful in giving a depth of 16 ft. across the bar. Further improvement, including dredging to $18 \mathrm{ft}$. across the bar and the straighteneing and widening of the channel inside, was authorized but the work delayed because of the question of where a breakwater should be built to create a harbor for commerce and refuge in the vicinity of Los Angeles.

In the same year that the little rallroad between Los Angeles and Wilmington got into operation, a transcontinental rallroad had been completed into San Francisco. Los Angeles and other intervening communities asked for the price of extending the rallroad down state. The price given Los Angeles was a cash payment representing five percent of the total assessed valuation of the county, a rightof-way, 60 acres for depot purposes, and, as a bonus, the little railroad to Wilmington. The offer was accepted and in 1876 the harbor was connected to a major rail line.

The town of Santa Monica was founded in 1875 and the founders, including the idea of making it a seaport, had built the Los Angeles and Independence Railroad terminating in a wharf extending some $1,800 \mathrm{ft}$. into the ocean. The chief anticipated commodity was ore to be shipped to San Francisco for processing. This railroad, its wharf and holdings were absorbed by the Southern Pacific in 1876.

The population of Los Angeles in 1872 was $8,000,20$ percent being Americans. By 1886 the population had increased to 15,000 in the city and 50,000 in the metropolitan area. In less than 20 months these figures increased to 70,000 and 200,000 respectively. The commerce of the harbor had increased from 50,000 tons in 1871 to 450,000 tons in 1888. This was sizeable tonnage and yet the harbor had no completely protected anchorage. Occasionally a vessel was driven ashore. These losses in ships and in their time brought a demand for a breakwater to create a harbor of refuge.

In 1886 the first of four different projects for a breakwater in San Pedro Bay was submitted to Congress. This proposed project by the Engineer officer in charge was to consist of two arms separated by a gap of 1,000 ft. The inner arm was to extend from the 3-fathom curve just off Point Fermin to about the 9-fathom 
curve, and the outer arm was to be a tangent approximately on that curve. The total estimated cost was $\$ 4,000,000$.

The River and Harbor Appropriations Bill passed early in 1890, included $\$ 5,000$ to be used to pay the expenses of preparing a project for a deep-water harbor "between Points Dume and Capistrano." The Board of Engineers appointed to make the report stated that the only possible locations were Santa Monica and San Pedro. This board recommended the latter location and proposed another breakwater of two arms. The inner arm of this breakwater was to extend from shore to the 6-fathom curve. A gap of 1,300 ft. permitted putting the outer arm in about the same location as that proposed in 1886, but made it $500 \mathrm{ft}$. longer. The total estimated cost was $\$ 4,500,000$.

It was generally assumed locally that the question was settled and the Los Angeles Chamber of Commerce requested immediate construction. Recitation of certain events which transpired from 1881 on is needed to explain why the construction was repeatedly deferred. The Southern Pacific Railroad with their terminal in wilmington became impatient in their wait for deep water to be brought into them and decided to go to deep water. Under state law with San Pedro unincorporated in 1881 they secured a right-of-way, reconfirmed in 1887 with some additions, which gave them almost the entire water front of San Pedro to the west jetty just inside of which was later constructed the Southern Pacific Slip. By purchase of land they also went on to Point Fermin and began the constmiction of a wharf approximately on the later site of the breakwater. This wharf was never completed or used. These combined moves gave this rallroad a monopoly on the western side of the harbor. On the other side of the harbor, however, other interests in 1891 bought Rattlesnake Island for $\$ 250,000$, changed its name to Terminal Island, and built a rallroad via Long Beach to Los Angeles. Their terminal was on the westerly tip of the Island.

This opening for a competing raliroad removed any possibility of a complete monopoly at the local harbor. At Santa Monica there was no competition. The railroad was extended a short distance to "Port Los Angeles" and construction of a second dock, known as the "long wharf," was begun. W1th the "long wharf" in operation deep inroads were made into San Pedro's commerce. However, breakwater protection was more essential at the new location than at Point Fermin.

Thus, it was that all attempts to get breakwater protection at Federal expense found the sponsors of Santa Monica striving to get the construction for their port. The controversy gained national prominence and much bitter argument went on both locally and in Washington.

As previously mentioned, an attempt to get an appropriation to carry on the authorized improvement of the inner harbor and its approach was denied until decision could be reached as to where the principal harbor w1th breakwater protection was to be located. To advise Congress in this regard another group of Army Eng1neers, known as the Craighill Board, was appointed in 1892. This board conducted a hearing in Los Angeles in July 1892. At this hearing, one of the points brought out was that the ra1l road had favored San Pedro and made it 1 ts headquarters for many years. The sudden change to Santa Monica was attributed to the ownership of all frontage at the latter location.

The Board's report was filed in October and presented to Congress in December of the same year. The report was unanimously in favor of San Pedro and proposed a continuous breakwater $8,500 \mathrm{ft}$. long on a curve to the Ine of the outer arm of the 1890 project and then a short distance along that line to the end. The est1mated cost was $\$ 2,885,324$.

Again the local reaction was that the question had been settled. The chamber of commerce sent a special delegation to try to get an immediate appropriation. The question didn't get out of the committee.

There followed several years of congressional bickering, followed by preparation of bills calling for $\$ 392,000$ to improve the inner harbor at San Pedro and $\$ 3,098,000$ to build breakwater at Santa Monica. For a time it seemed that this would be the final decision, for the committee on commerce of the Senate voted to restore the Santa Monica $\pm t e m$, which, in the interim, had been stricken from the 


\section{COASTAL ENGINEERING}

bill. Senator White of California carried on the debate for five consecutive days and finally succeeded, with considerable help from newspapers and the general public, in getting an amendment providing for an appropriation of $\$ 2,900,000$ and the appointment of a new commission of unprejudiced members. The decision of this board was to be final as to where the money should be spent.

President Cleveland in October, 1896, appointed the members of this board. He named Rear Admiral John G. Walker from the Navy, Augustus F. Rodgers from the Coast and Geodetic Suryey, and William H. Burr, George S. Morrison, and Richard P. Morgan from civil life. This board made a thorough investigation, including soundings, and borings and prepared new maps. The conclusion of its report read: "Taking all considerations together, this board reports in favor of San Pedro as the location for a deep water harbor for commerce and of refuge in Southern California."

There was still some delay and threat of nullifying action, but in February, 1898 , bids were opened. The low bid was for $\$ 1,303,198$, less than one-half of the estimated cost. An effort in the senate to get the indicated balance of about $\$ 1,600,000$ expended pro rata upon both Santa Monica and San Pedro was promptly voted down.

On April 26, 1899, more than a year after award of contract, the first barge of rock from Catalina. Island was dumped on the site. The event called for celebration, which was termed the Free Harbor Jubliee. This began with firing of cannon, speeches, and barbecue at San Pedro on the first day. On the second day, the scene shifted to Los Angeles where more than 100,000 persons watched a floral parade.

Progress of this contractor was so slow that his contract was cancelled and new bids invited. On May 14, 1890, another contract calling for $\$ 2,375,546.50$ was let. Work was resumed in August of 1900 and proceeded without starting incident to completion of the contract. The first contractor brought by scow and dumped about 90,000 tons of rock, referred to as andesite, from catalina. The second contractor used a double-track-standard-gauge railway trestle, bullding a considerable part of the substructure with sandstone from Chatsworth at the head of San Fernando Valley, and the balance with granite from several sites in the vicinity of Riverside. The contractor used two steam shovels converted into traveling cranes for unloading and disposing of the heaviest stones both superstructure and substructure. These cranes were stabllized as needed both by steel guys to the opposite track where the loaded cars were resting, and by rollers carried in heavy brackets on both sides of the front of crane which rested on a platform 4 ft. wide of $12 \times 12$ timbers, in turn supported by heavy timbers reaching from cap-to-cap of the trestle bents. Smaller stones were thrown and pried from the cars by hand. The substructure was bullt as they worked out to the end, and the superstructure as they worked back toward shore removing the interfering parts of the trestle.

Both the location and the design were included in the Walker Board report. The stmucture was to be detached, beginning in 4 fathoms of water about $1,900 \mathrm{ft}$. from shore. The first section was a 3,000-ft. tangent in a southeasterly direction followed by a curve $1,800 \mathrm{ft}$. Iong, with radius of $1,910 \mathrm{ft}$. , and ending in another tangent 3,700 ft. long roughly along the 8-fathom contour. Even with a cancelled contract involved, funds were sufficient to permit extending the outer tangent $750 \mathrm{ft}$. , making the total length 9,250 ft. Instead of 8,500 ft. as planned.

As designed, the breakwater was to be all stone with a width of $38 \mathrm{ft}$. at mean lower low water, the dividing line between sub- and superstructure. Below this plane, the substructure was to be muble mound with slope of 1 vertical on 1.3 horizontal throughout on the harbor side and below minus 12 ft. on the ocean side. The slope from low tide to minus $12 \mathrm{ft}$. on the seaward side was prescribed as 1 on 3 . Stones were to range from $100 \mathrm{Ibs}$. upward, with two-thirds averaging over 1,000 lbs. each.

The superstructure $14 \mathrm{ft}$. high and $20 \mathrm{ft}$. wide on top, was to consist of two walls and a roof of rectangular blocks of granite with interior solidly filled with random stone. On the ocean side the wall rises the $14 \mathrm{ft}$. in 4 courses, each 3-1/2 ft. thick, and retreating $3 \mathrm{ft} .4 \mathrm{in.}$. in each lift for a total of $10 \mathrm{ft}$. No stone on the ocean side weighs less than 8 tons. On the harbor side the rise is 
made in 7 courses of $2 \mathrm{ft}$. each with retreat toward center of $1 \mathrm{ft}$. 4 in. In each Iift for a total of $8 \mathrm{ft}^{\prime}$. No stone on the harbor side of the superstructure weighs less than 3 tons.

In the design the base of the superstructure was the same width as the top of the substructure. This lack of shoulder, particularly on the harbor side with its uniformly steep slope, caused concern early in the construction to end that a berm of about $4 \mathrm{ft}$. was used on practically all of the harbor side. A corresponding berm averaging perhaps $5 \mathrm{ft}$. was used on a large part of the ocean side. Along this side in many places additional unshaped stone was added on top of the berm with the intent of insuring the bottom layer of the shaped stone.

This detached breakwater was completed on September 9, 1910. During its construction, the advisability of the 1,900-ft. gap between it and shore was given reconsideration. It had been left as a secondary entrance and to encourage free clrculation of water on theory that sewage and debris would leave faster and shoaling inside would be retarded. However, rocks and a kelp bed off point Fermin made it uninviting as an entrance and storms drove the kelp inside and created a large area of rough water inside. By 1908 a project had been secured to connect the breakwater with shore. This section was undertaken shortly after completion of the detached section and completed in 1912.

The design of the Walker Board was not used in closing the gap. A random mound of the same top helght and width was used because it was substantially cheaper. It withstood the seas equally well and less water passed over its top due to the extreme irregularity and the large volds recelving the seas on the installment plan and providing escape ways for much of their waters other than upwards. The speclal superstructure with the rectangular blocks under certain circumstances could prove the cheaper. It enables steep side slopes, which permit narrowing of the substructure. This could be the basis for a big saving particularly in deep water. However, unless stratified rock were available to make the blocks relatively cheap, the larger cross section required without them could still be filled and money saved. The second contractor on the detached section, largely due to the cost of preparing the rectangular pieces, needed the aid of creditors, profits from other jobs, and the savings of a lifetime to finish the job.

Congress charged the Walker Board with the duty of locating a harbor not only of refuge but of commerce. How farsighted 1ts members were is well shown by the following paragraph quoted from the Board's report -- "At San Pedro a large expenditure has already been made for the improvement of the channel leading into the inner harbor and in the inner harbor 1tself. The sertes of examinations made under the direction of this Board also show that any further improvement that may be needed can be readily made, and that the possibilities for the further development of the interior harbor are equal to any demand upon it which the future can be expected to make."

The Corps of Engineers created the Los Angeles District in 1899, and the first District Englneer, in compliance with the Act of March 3 of that year, had a new complete survey made of the whole harbor and recommended a project which called for the improvement of the whole inner harbor to a depth of $30 \mathrm{ft}$. This contemplated the dredging of $20,000,000$ cubic yards at an estimated cost of $\$ 2,159,100$. However, he proposed working first on that part extending up to and including the turning basin south of Mormon Island to a depth of $24 \mathrm{ft}$. and average width of $400 \mathrm{ft}$. at a cost of $\$ 550,000$. When Washington assumed the attitude that this latter partial project, under way in 1903, was the project, people locally became alarmed and wondered if acquisition of title to seven-eighths of wilmington Bay above and to the sides of the turning basin, by private interests under railroad control, was going to prevent full development of a free harbor, publicly controlled.

The title to this submerged, tide and marshland had been gained through perversion of law and later was declared invalid. But it posed a real threat at the time. In 1850 the Federal Government had granted by what is known as the "Arkansas Act," unapproprlated swamp and overflow lands, including marshlands, to the states. The State patents in this Wilmington Bay case were obtained between March 5,1880 and January 16, 1891 under the General Law of 1868, Chapter 415, as amended in 
1870, for management and sale of "Swamp and overflowed, salt marsh and t1de lands," the purpose of which general law was that swamp and overflowed lands should be reclaimed for agricultural purposes.

Local people felt the best way to bring the issue to a head was to press for the establishment of harbor lines. Thus, the rematch between the same opponents was on. The controversy did not gain the national prominence that the fight for the breakwater did, but locally and in Washington it was as tense and bitter. The good that came from the struggle was the time it provided and the interest it aroused in the plan of development for the inner harbor.

The Southern Pacific crossing to San Pedro in 1881 had severed the inner bay by trestle, which had been converted into fill. That part of the bay known as West Basin had been isolated. Immediately to the east of the railroad was the turning basin of the "partial project" and beyond that the East Basin. The Harbor Line Board appointed in response to the demand of 1903, delineated two large basins. The one east of the railroad varied in width from 1,500 to 2,400 feet and was about 3,200 feet long, providing room for ships to anchor as well as maneuver. The West Basin though smaller was outlined in the same general way. The distance between bulkhead and plerhead lines was $600 \mathrm{ft}$. to permit open-pile plers where there was lowland sufflcient to warrant, and less at other places.

Following the submission of recommended lines in 1905, came the ruling from Washington that the War Department had no authority to establish harbor IInes beyond the turning basin. The reasoning advanced was that beyond the project no harbor existed in which to establish lines.

In December, 1906, an application was made for permit to develop the inner bay east of the railroad by the digging of two channels each 1,000 ft. wide, with a reclalmed peninsula, varying in width from 1,100 to $2,000 \mathrm{ft}$. and 9,000 ft. long, lying between them. In the prolonged study of this application, the district office evolved plans of 1 ts own and in forwarding the application with unfavorable recommendation submitted a plan for the development for the entire inner harbor, both east and west of the railroad. This plan provided for the two basins, but reduced the water areas to that actually required for maneuvering and passing purposes and made plerhead and bulkhead lines only $40 \mathrm{ft}$. apart. A minor Y-shaped basin was proposed in front of the old landing in Wilmington. Areas to be reclaimed were so arranged that slips could be dredged into the land when more water frontage was needed. Various adaptations of the plan to show its possibilities fairly bristled with slips.

The previous conception of the outer harbor had been changed by advancing the bulkhead line into water sufficiently deep to allow reclamation of considerable areas so essential in the shore end of water commerce, and providing for two channels 400 and $600 \mathrm{ft}$. wide and 2,600 and 4,000 ft. long. The outer ends of the peninsulas thus formed remain unreclaimed but available today.

The guiding thought for the inner-harbor development and establishment of controlling lines was stated by D. E. Hughes at the time (February, 1907), in the following words:

"Since neither tidal prism nor anchorage area would be of any use in this inner harbor, it would be an inexcusable waste to dredge more than is sufflcient for the easy passage, berthing and turning of ships, and the rest of the reserved area should be reclaimed under Government control for the regulation of commerce. Such reclamation is also desirable for the reason that, through providing room near at hand for the disposal of dredgings, it would greatly reduce the cost of excavating the channels and slips."

"The land reclaimed should never be alienated, but held as a public water front under control of Federal or state authority for the regulation of commerce."

What started as a paper is fast running into a book, so it will be necessary to omit recording of many moves and state that a joint resolution of Congress in March, 1908, caused the appointment of another Harbor Iine Board in April. Th1s Board submitted 1ts report in July and the Secretary of War approved the 11nes the 


\section{HISTORY OF LOS ANGELES HARBOR}

same month. Though they have been modified a number of times, particularly to permit widening of the Main Channel to $1,000 \mathrm{ft}$, the lines cast the die for the development of the harbor of commerce. The offlcial approval also reaffirmed the authority to establish lines in navigable waters in advance of improvement in order to regulate 1t, and regardless of ownership, real or claimed, of the underlying land.

Suit was instituted by the state in 1908 to recover the patented lands in Wilmington Bay on the ground that the patents were invalid. A decision declaring many of the patents vold was rendered in the Superior Court of Los Angeles County in January, 1911. This decision was confirmed by the supreme Court of the state in 1912. Patents on two parcels were declared valid, but the ownership "subject to the public easements for navigation and fishery, and the state of California is declared to be the owner of all interest and title therein necessary to the support of said easements." In other words, these patentees had naked title.

For many good reasons the city of Los Angeles desired to bring the harbor within the city. From the time of authorization of the construction of the Panama Canal, the advantages in the matter of "terminal rate," new steamship 11nes, etc., could be foreseen, not to mention the prestige of having the city a seaport. W11mington and San Pedro had seen and enjoyed enough of the political power of the c1ty in the various controversies to appreclate that theirs were weak voices without 1t. They also were not unmindful of the necessity for large expenditures of local money for terminal and other purposes and realized the limits of their bonding capacities.

The first step of the city in its move toward the harbor was the annexation of a strip of unincorporated territory along Vermont Street from Manchester street to the town of Wilmington. Sentiment in both Wilmington and San Pedro seemed to favor the consolidation, but state law provided that only cities of first class could consolidate. Los Angeles was flrst class, but San Pedro was fifth class and Wilmington sixth class at the time. Hence, legislative action was necessary. This action was blocked for a number of sessions, particularly by a state Senator who was from San Pedro, and who declared Los Angeles wanted to gobble his town. To circumvent this situation, proponents of consolidation circulated a petition for an election to exclude a part of San Pedro from the town, which would reduce 1ts size sufficlently that the remaining portion could disincorporate under state law, and all would be eligible for annexation. After submission of the petition, the proponents got cold feet fearing that Long Beach might annex the excluded portion while the balance was getting disincorporated. A court order forced this election and those who had circulated the petition worked hardest to defeat the exclusion. The new consolidation bill passed the legislature a few days before the election and exclusion was voted down. Consolidation elections followed and the vote in both towns was favorable to the action -- Wilmington first and then San Pedro in August, 1909, by a 3 to 1 vote.

The Improvement of the outer harbor began several years before consolidation. The Southern Paciflc secured a franchise from the city of San Pedro and built its slip just inside the west jetty. Another franchise for the Miner fill and adjacent channels outside the west jetty was used and the improvement made. Huntington and associates had a concession for a mole also outside the west jetty between the Main Channel and the Miner fill, and intended using material dredged from the Southern Pacific slip to construct it. The excavation only provided about half enough material and the dredgings spread over the tideland unconfined. After consolidation, Los Angeles brought a consulting engineer from New York to advise upon the sequence and type of construction and upon his recommendation the Huntington concession was revoked and the city built the mole (known as Pler One) and a large concrete warehouse upon 1t. Here was recently established the forelgn-trade zone authorized by the Secretary of commerce.

On May 1, 1911, the state granted to Los Angeles all of the former's right and title to the tide and submerged land within the "consolidated clty." These lands were, of course, to be held in trust for commerce, navigation and fishery. The leasing of land for other purposes for limited perlods when not required for the primary purpose has been adjudged to be not inconsistent with the trust. The 
city's alert and vigorous prosecution of suits to recover all such lands erroneously alienated and the purchase of the Southern Pacific's right-of-way along the San Pedro water front has resulted in almost absolute control and ownership of the harbor and the water front by the municipality. In the successful sult to revoke the Miner fill franchise, the cost of the teminal facilities made in good falth became the consideration for a long-term lease to the builders. At Fort MacArthur and Reservation Point, the Federal Government, through state law ceding the foreshore of military reservations, is the owner of formerly submerged land now reclaimed.

The development of West Basin began in 1911, when the Federal Government not only ordered a drawbridge installed in the railway lines to make entrance into the basin possible, but also let a contract for a channel $200 \mathrm{ft}$. wide through the bridge and along the east side of the basin.

Development of Long Beach Harbor began in 1906, when the Los Angeles Dock and Terminal Company, a private corporation, bought 800 acres of marshland and tidal sloughs. This company secured a permit from the War Department to dredge certain channels. It also succeeded in forcing the railroad to replace a trestle across the old river mouth with a bascule bridge having $180 \mathrm{ft}$. of span. The plan of improvement consisted of an entrance channel protected by jetties on either side, an interior turning basin, and three channels extending northerly and easterly from the basin. All of this exists today as Long Beach Inner Harbor except the channel to the north, which was surrendered to induce industrial development.

In 1909, the Clty of Long Beach sold bonds and bought some frontage on its Inner Harbor and improved it with a terminal. In 1916, the city received a deed to the channels, turning basin, and about five acres near its pier from the company, which had experienced great difficulty in getting on with the dredging as the project was at the mouth of a river, which did have floods carrying large quantities of material in suspension which settled out in calm water.

Owning so little of the frontage in the Inner Harbor prompted Iong Beach to turn in 1924 to the creation and development of an Outer Harbor with breakwater and moles. This Outer Harbor is still being improved with mole piers and fine transit sheds. The last bond issue for harbor purposes in Long Beach was in 1928 . 011 was discovered in 1936, and the returns from oil development of city-owned property has carried the financial load very nicely since that time.

Los Angeles and Long Beach Harbors early had two common desires. One was to have river flood-waters permanently diverted. The other was to have direct water connection between the two inner harbors. River diversion was considered early in the development of Wilmington Bay and, had it been effected as then proposed, it would have consisted of a dike forcing all flood waters out where Long Beach Inner Harbor was later built. In this event there would have been no two harbors to connect.

A far-sighted District Engineer noting the narrow, sinuous natural channels legally subject to improvement for navigation, agreed with the railroad company owning the last land that in exchange for an easement with parallel sides to provide a direct connecting channel between the two harbors, he would recommend a permit to allow the company to reclaim the small and twisting tidal channels outside the easement. Initial connection was by combined effort of the Federal Government and the C1ty of Long Beach. Later enlarging of this Cerritos Channel made possible by additional easement was done by the Govermment.

The floods of 1914 and 1916 hastened the construction of river diversion. The profect consisting of an intercepting dike at high land at Dominguez and nearly five miles of channel to the sea between the City of Long Beach and 1ts harbor was started in 1919 and completed in 1923. It was a Federal harbor project with many conditions of local cooperation including provision of right-of-way and bridges and assumption of operation and maintenance by a responsible agency. The created agency was the Los Angeles County Flood Control District.

In 1928, the Federal Government completed the removal of Deadman's Island and the reclamation of Reservation Point in a project which widened the Main Channel of Los Angeles Harbor to a minimum of $1,000 \mathrm{ft}$. up as far as the turning basin. 


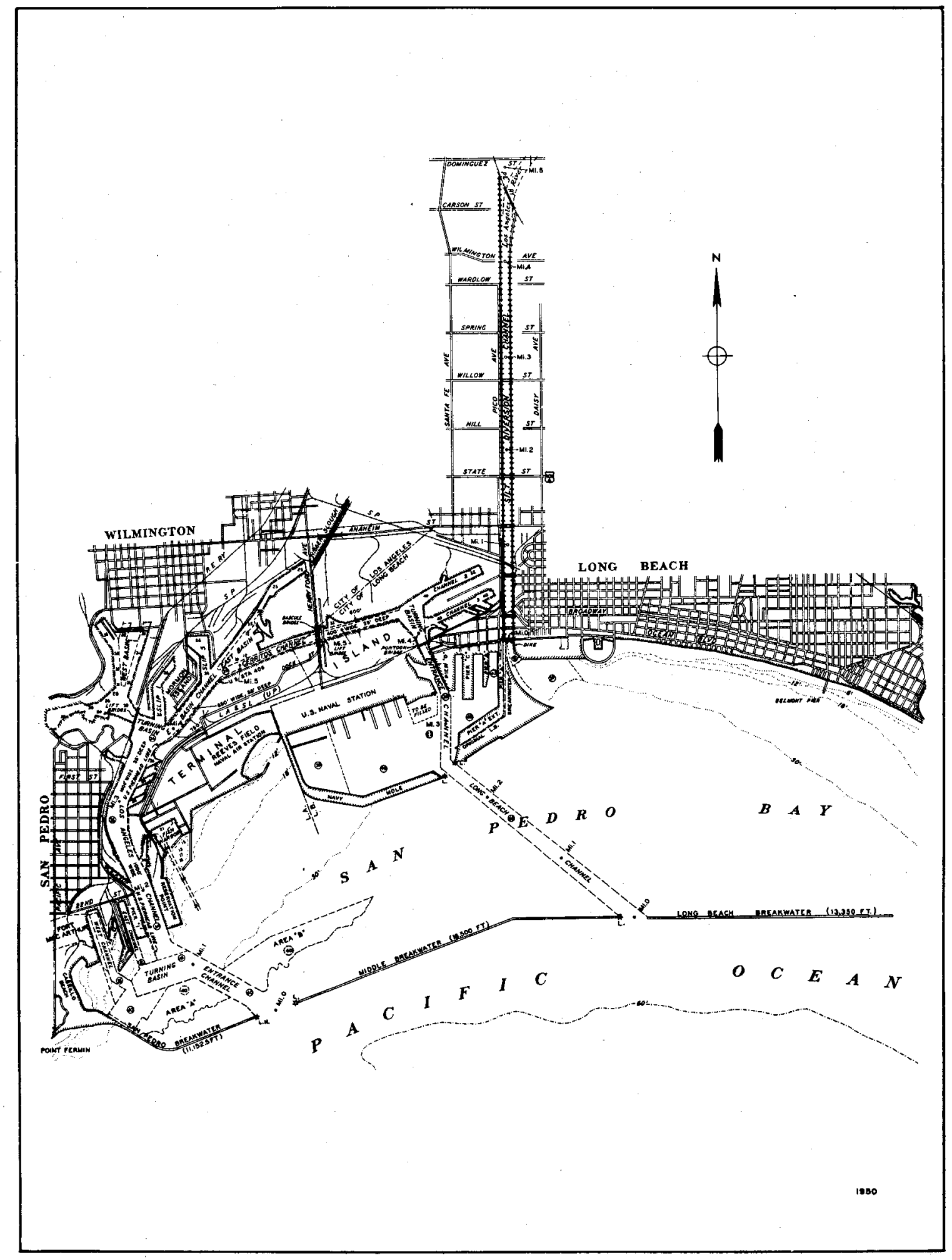

Fig. 2 
Breakwater extension to further protect the outer harbors and the face of Terminal Island was discussed for many years. The first project for this purpose was authorized in 1925, and provided for an all rock breakwater. Leaving an opening of 2,000 ft. at the end of the San Pedro Breakwater, the new structure was to continue in prolongation of the outer arm of the old breakwater for about 2-1/2 miles. After another opening, a second arm was to connect to shore at the west side of the flood-diversion channel mouth, making all discharge from that channel outside the harbor.

Many conditions of local cooperation were contained, including contribution of half the cost (estimated to total $\$ 14,000,000$ ), unification of control of the two harbors, creation of a belt-line railroad, closure of a long length of cerritos Channel -- Terminal would no longer be an island -- and others. Long Beach built its breakwater with inner arm in prolongation of the west bank of the flood control hoping to qualify its cost as part of the contribution. other efforts were made to comply, but it became apparent that to meet them all would be Impossible.

In 1930, a new project was authorized, which eliminated the arm to shore. Contemplating the use of dredgings from project areas in Los Angeles Outer Harbor in the base and hearting of the breakwater instead of making it all rock the total estimated cost was reduced to $\$ 7,000,000$, the amount the Government was prepared to assume in the first project. This caused dropping of the local contribution condition. All the other conditions were also dropped. This composite breakwater, starting with an experimental earthen mound on the site in 1932, was completed in 1937. Extension of this breakwater chain with the same type of construction due east another 21,150 ft., including one 1,800-ft. opening, was completed in 1949 (Fig. 2).

As is evident, the writer, unable to include pertinent detail for the complete history of the harbor, has chosen to emphasize the early formative stages and has sklpped lightly over the more recent expansion. To those interested, later history is readily available together with statistics of every sort. The roadstead in the lee of Point Fermin has developed into twin harbors whose combined annual tonnage has on occasion exceeded 32,000,000, and which together have an approximate 23 miles of improved wharves with more in process and projected. 